\title{
Precursors and outcome of satisfaction in business-to-business relationship building: An information communication technology industry perspective in South Africa
}

\begin{tabular}{|c|c|}
\hline \multicolumn{2}{|c|}{$\begin{array}{l}\text { Authors: } \\
\text { Mpho Hlefana }{ }^{1} \text { (1) } \\
\text { Mornay Roberts-Lombard }{ }^{1} \text { (๑) } \\
\text { Beate E. Stiehler-Mulder }{ }^{1} \text { ( }\end{array}$} \\
\hline \multicolumn{2}{|c|}{$\begin{array}{l}\text { Affiliations: } \\
\text { 'Department of Marketing } \\
\text { Management, University of } \\
\text { Johannesburg, Johannesburg, } \\
\text { South Africa }\end{array}$} \\
\hline \multicolumn{2}{|c|}{$\begin{array}{l}\text { Corresponding author: } \\
\text { Mornay Roberts-Lombard, } \\
\text { mornayrl@uj.ac.za }\end{array}$} \\
\hline \multicolumn{2}{|c|}{$\begin{array}{l}\text { Dates: } \\
\text { Received: } 12 \text { Mar. } 2019 \\
\text { Accepted: } 27 \text { Nov. } 2019 \\
\text { Published: } 30 \text { Apr. } 2020\end{array}$} \\
\hline \multicolumn{2}{|c|}{$\begin{array}{l}\text { How to cite this article: } \\
\text { Hlefana, M., Roberts-Lombard, } \\
\text { M. \& Stiehler-Mulder, B.E., } \\
\text { 2020, 'Precursors and } \\
\text { outcome of satisfaction in } \\
\text { business-to-business } \\
\text { relationship building: An } \\
\text { information communication } \\
\text { technology industry } \\
\text { perspective in South Africa', } \\
\text { Acta Commercii 20(1), a777. } \\
\text { https://doi.org/10.4102/ac. } \\
\text { v20i1.777 }\end{array}$} \\
\hline \multicolumn{2}{|c|}{$\begin{array}{l}\text { Copyright: } \\
\text { (c) 2020. The Authors. } \\
\text { Licensee: AOSIS. This wc } \\
\text { is licensed under the } \\
\text { Creative Commons } \\
\text { Attribution License. }\end{array}$} \\
\hline \multicolumn{2}{|l|}{ Read online: } \\
\hline 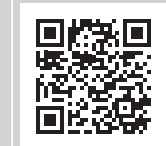 & $\begin{array}{l}\text { Scan this QR } \\
\text { code with your } \\
\text { smart phone or } \\
\text { mobile device } \\
\text { to read online. }\end{array}$ \\
\hline
\end{tabular}

Orientation: To secure a competitive business position, mobile business service providers need to explore the factors that, in predicting customer loyalty, will enable them to focus marketing efforts on improving their current customer management strategy, ultimately leading to enhanced satisfaction.

Research purpose: This study intended to determine the influence of selected customer relationship management factors on customer satisfaction and customer loyalty.

Motivation for the study: To ensure the loyalty of their customer base, mobile business service providers need to understand the factors that secure customer satisfaction in a competitive ICT business-to-business (B2B) market.

Research design, approach and method: Data were gathered by means of a self-administered questionnaire, and a total of 253 responses were eligible for analysis. Simple regression analysis was applied to validate the hypotheses formulated.

Main findings: It was established that corporate image, service quality, perceived value, customisation and trust have a significant and positive influence on ICT business customer satisfaction and loyalty.

Practical/managerial implications: The findings suggest that efforts towards improving corporate image, service quality and customer perception of the value provided, focusing on the level of customisation and establishing trust among business customers will aid B2B mobile service providers in achieving satisfied and loyal customers.

Contribution/value-add: This study adds to the body of knowledge by identifying and demonstrating the influence of five customer relationship management factors that contribute to achieving customer satisfaction and loyalty in the Business-to-business information communication technology (B2B ICT) industry of an emerging African market.

Keywords: B2B; corporate image; customisation; customer loyalty; perceived value; service quality; satisfaction; trust.

\section{Introduction}

Price wars, shortened product lifecycles and newly emerging markets define the state of competition in the information communication technology (ICT) industry of South Africa. Specifically, the business-to-business (B2B) sector of the ICT industry in the country has reported intense competition and a decline in profits in market share as a result of these trends (Accenture 2012). In the fight to maintain market share and profit margins, customer relationship management becomes a key factor in retaining business customers and keeping them loyal in the ICT industry of South Africa as an emerging African market.

Customer relationship management (CRM) is a contemporary marketing topic that is gaining momentum because of growing competition, customers who are becoming more informed and changes in consumer preferences. Organisations increasingly recognise the growing importance of CRM as a tool that can be used to gain new customers, retain customers, increase customer 
lifetime value and create a sustainable competitive advantage for service organisations (Ndubisi, Malhotra \& Miller 2015; Nyadzayo \& Roberts-Lombard 2010). Several research studies have explored the various interrelationships between customer satisfaction, its antecedents (corporate image, service quality, perceived value, customisation and trust) and its outcome (customer loyalty) from different perspectives. However, limited research has explored how customer satisfaction relates to its antecedents and outcome in the ICT industry of an emerging African market such as South Africa.

This study therefore focused on assessing how selected CRM factors influence customers' satisfaction and loyalty and explores the relationship between satisfaction and loyalty in a B2B environment. The CRM factors identified for inclusion in this study are corporate brand image, service quality, perceived value, trust and customisation, which are argued to influence customer satisfaction and customer loyalty (Coelho \& Henseler 2012; Handriana 2016; Tu, Li \& Hsu 2013). Satisfied customers are more likely to share their experiences of brands with others, make recommendations about products and services, and engage in repurchase behaviour (Nuseir \& Madanat 2015). To obtain customer loyalty, organisations need to ensure high levels of satisfaction (Jokela \& Söderman 2017). Therefore, an assessment of the influence of selected CRM factors on customer satisfaction at an identified ICT service provider in South Africa should assist organisations to improve its service efforts for business customers. This would, in turn, foster stronger relationships with business customers to strengthen customer loyalty in the long term.

The study makes a clear contribution to the theory by indicating that the previously identified relationships between customer satisfaction and its antecedents and outcome are also evident in the context of the ICT industry of an emerging market, specifically in the relationships between the customer satisfaction construct, its antecedents (corporate image, service quality, perceived value, customisation and trust) and customer loyalty as an outcome. A proposed model is provided and validated that shows the B2B relationships between customer satisfaction, its antecedents and customer loyalty within the South African ICT industry. The research contributes to business practice by assisting a selected ICT service provider to understand how corporate image, service quality, perceived value, customisation and trust can nurture customer satisfaction, which can eventually lead to the long-term customer loyalty of its business customers.

This article first describes the context of the study, expounds the theories grounding the study and explains its key constructs. The hypotheses for the study are presented and a theoretical model is proposed. The research methodology is described, followed by the results, the findings and the managerial implications of the study.

\section{Theoretical framework}

\section{The information communication technology industry in a business-to-business context in South Africa}

South Africa's ICT industry is very diverse and has many components, such as information technology (IT), telecommunications and media broadcasting. Accordingly, ICT is defined as 'consisting of the hardware, software, networks and media for the collection, storage, processing, transmission and presentation of information (voice, data text, images), as well as related services' (Department of Telecommunications and Postal Services 2014). The ICT industry is a key contributor to South Africa's gross domestic product (Statistics South Africa 2015). Swiss Business Hub South Africa (2014) suggests that the industry may be worth R200 billion by 2020, with IT outsourcing services contributing towards $40 \%$. Leading ICT organisations in South Africa, such as the ICT provider selected for this study, provide IT and telecommunications products and services, systems integration, installation and support services to other organisations in the form of outsourcing part or all of their ICT functions. This type of trading forms part of the B2B market. Product lifecycles in the B2B market, and in particular for ICT, are fairly short because of the rapid pace at which technology changes. The short lifecycle of ICT products has resulted in regular innovation, paving the way for more competition (Selvam \& Kalyanasundaram 2015; National Treasury 2016).

\section{Relationship marketing theory grounding the study}

Adopting long-term relationships with customers through relationship building activities has become a source of competitive advantage, particularly for service organisations (Jemaa \& Tournois 2014; Larentis, Antonello \& Slongo 2017). According to Negi and Ketema (2010), relationship marketing is a strategic approach to forming relationships with customers, suppliers and other business stakeholders, through targeted means, to increase an organisation's returns. However, it is important to note that such relationships should be beneficial to all parties involved in a service transaction (Rootman, Tait \& Sharp 2011). A relational approach to doing business encompasses more than just recruiting new customers. It also involves tactics that encourage customer loyalty, foster supplier buy-in to provide superior service and garner support from other stakeholders. Customers are likely to remain loyal to an organisation that manages relationships proficiently (Melewar et al. 2017). Managing relationships in a highly organised manner requires organisations to execute a relationship marketing strategy using the right people, processes and tools. Customer relationship management is an enabler for relationship marketing strategies and involves managing customer relationships in an organised manner using systems and technologies (Bhat \& Darzi 2016). Customer relationship management is therefore imperative for the successful management of customer relationships in the long term. 


\section{Corporate image and its relationship to customer satisfaction and customer loyalty}

Corporate image refers to the collective perception that customers establish about an organisation in their numerous encounters and experiences with its brand. Malik, Ghafoor and Iqbal (2012) propose that brand image contributes to customer satisfaction. Ali et al. (2016) found that customer satisfaction has the largest influence on customer loyalty. Van Vuuren, Roberts-Lombard and Van Tonder (2012) argue that corporate image is a key factor in creating customer loyalty and fostering repeat purchases. As part of corporate image, brand image is a key topic for service organisations as it influences product or service marketing. In turn, brand image plays a role in customer satisfaction (Malik et al. 2012). These authors further established that service quality, price and brand image are all predictors of customer satisfaction and drivers of customer loyalty (Tu et al. 2013). Daviesh and Chun (cited in Tu et al. 2013:183) suggest that corporate brand image fosters customer loyalty, because it creates customer satisfaction. Considering this, the following hypotheses are formulated:

H1: A significant and positive relationship exists between corporate image and customer satisfaction.

H7: A significant and positive relationship exists between corporate image and customer loyalty.

\section{Service quality and its relationship to customer satisfaction and customer loyalty}

Haghighikhah, Khadang and Arabi (2016) remark that service quality is a crucial factor in manufacturing and service organisations. Botha and Van Rensburg (2010) concur and argue that satisfaction and service quality link up through a causal relationship whereby service quality perceptions affect satisfaction and satisfaction influences a customer's loyalty. A customer's satisfaction level is based on a perception of the value they receive. Service providers therefore need to consider individual customer evaluations of service and not focus only on the sum of all customer evaluations. Equally important to consider is that customers' evaluation of service quality is twofold. Firstly, the quality of each service encounter is assessed, and second, the level of satisfaction is based on service encounters over time (Petzer and De Meyer 2011). It can be argued that service quality, as a precursor to customer satisfaction and ultimately loyalty, affects both customer satisfaction and customer loyalty. In this regard, the following hypotheses are formulated:

H2: A significant and positive relationship exists between service quality and customer satisfaction.

H8: A significant and positive relationship exists between service quality and customer loyalty.

\section{Perceived value and its relationship to customer satisfaction and customer loyalty}

Perceived value is the difference between what the customer receives and the monetary sacrifice they make in exchange
(Lee 2010). Ariff et al. (2012) suggest that perceived value is a key differentiator in highly competitive business environments and that the creation of value converts consumers into customers. Tu, Li and Chih (2011) concur and state that perceived value directly affects customer loyalty. Lee (2010) also argues that perceived value is a precursor to customer satisfaction and that it plays a mediating role between perceived value and customer loyalty. Customers who believe that they are receiving value are likely to purchase frequently in larger quantities and desist from switching to a different supplier (Ndubisi et al. 2015). Against this background, the following hypotheses are formulated:

H3: A significant and positive relationship exists between perceived value and customer satisfaction.

H9: A significant and positive relationship exists between perceived value and customer loyalty.

\section{Customisation and its relationship to customer satisfaction and customer loyalty}

Customisation refers to the development of products and services based on the needs and wants of customers (Bojei et al. 2013). Providing customised products and services creates a competitive advantage for companies (Chuah, Marimuthu \& Ramayah 2014). Bojei et al. (2013) argue that customisation can be perceived as a precursor of loyalty. A study by Lewis and Soureli (2006) in the banking service industry established that customisation has an impact on service or product quality, which, in turn, has a direct effect on customer loyalty. Coelho and Henseler (2012) concur and argue that customisation can increase service quality, trust and satisfaction before impacting customer loyalty. The following hypotheses are therefore formulated:

H4: A significant and positive relationship exists between customisation and customer satisfaction.

H10: A significant and positive relationship exists between customisation and customer loyalty.

\section{Trust and its relationship to customer satisfaction and customer loyalty}

In the academic literature, trust is perceived as an important precursor to fostering steady and mutually beneficial relationships and is important when building relationships (Bilgihan 2016; Upamannyu et al. 2015). Trust is present when a partner to a business relationship has confidence in another partner's integrity and perceives them as reliable (Theron, Terblanche \& Boshoff 2012). Accordingly, a customer is willing to engage in a long-term relationship with a supplier who caters for their needs or meet their expectations. If a brand consistently delivers on customer expectations in the long term, a customer is more likely to become loyal. The construct of trust is important in supplier-business relationships, because customers buy products and services based on trust. Over time, trust enables companies to gain a sustainable competitive advantage (Nguyen, Leclerc \& LeBlanc 2013). A customer may overlook a supplier's 
questionable service if the customer believes in the supplier's ability to deliver consistently. Considering this, the following hypotheses are formulated:

H5: A significant and positive relationship exists between trust and customer satisfaction.

H11: A significant and positive relationship exists between trust and customer loyalty.

\section{The link between customer satisfaction and customer loyalty}

Cheng et al. (2017:398) refer to customer satisfaction as 'the outcome of comparing service performance with expectation'. It relates to a decision that the feature of a product or service, or even the product or service as such, provided an enjoyable consumption experience that results in a feeling of contentment (Nyadzayo \& Roberts-Lombard 2010). Lassoued and Hobbs (2015) suggest that the feeling of satisfaction influences customers' desire to engage in repurchase behaviour. To ensure that customers are satisfied, organisations need to pre-empt customer needs and determine how best to satisfy those needs (Handriana 2016). These needs may be influenced by variables specific to an organisation or industry. Satisfied customers tend to use a product or service more than those who are not satisfied. However, Van Vuuren et al. (2012) contend that despite the emphasis on customer satisfaction, some satisfied customers may defect. Customer satisfaction is therefore not a guarantee that a customer will become loyal. Service providers should therefore find out what the reason for the defection is to respond effectively and try to retain the customer (Gong \& Yi 2018). In this regard, the following hypothesis is formulated:

H6: A positive relationship exists between customer satisfaction and customer loyalty.

Figure 1 illustrates the research model proposed for the study. It reflects the different constructs included in the study and their hypothesised relationships.

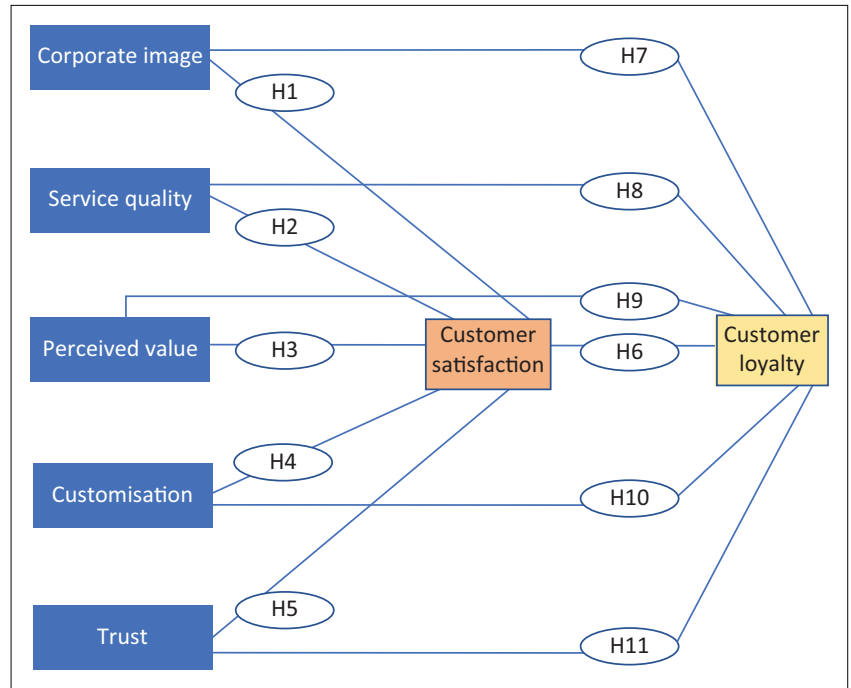

FIGURE 1: Proposed theoretical model.

\section{Research method and design}

Research approach, target population, sampling and measurement instrument

This study made use of a descriptive research design that was quantitative in nature and grounded on an interpretive paradigm. The population comprised the business customers of a selected ICT service provider who had purchased and made use of the company's business solutions and services for a period of 6 months or longer. The respondents were juniorlevel executives, managers and other staff working at selected business customer groups. Screening questions were applied to the study to make sure that the selected samples do meet the set requirements to take part in the study. Non-probability sampling technique was followed and 50 fieldworkers residing across South Africa were used to secure data collection from respondents. Fieldworkers were orientated towards the aim of the study, as well as the different constructs and items contained in the questionnaire. In addition, fieldworkers were required to fill ranking and contract duration quotas purposefully to ensure the target population was adequately presented. As a result, the selection of the sample was grounded on non-probability sampling by filling predetermined quotas purposefully. The respondents had to complete self-administered paper-based questionnaires and return the completed questionnaires to the fieldworkers. Data were collected over a period of 2 weeks.

The questionnaire used for the study was adapted from the studies conducted by Carvajal et al. (2011), Dagger and Sweeney (2007), Du Plessis (2010), Ndubisi, Malhotra and Chan (2009), Quoquab, Basiruddin and Rasid (2013), Theron, Terblanche \& Boshoff (2008), and Yang and Peterson (2004). The use of items from previous studies strengthens credibility and validity as various items of the survey have already been designed to determine factors that influence customer loyalty in B2B relationships. All items were measured using a sevenpoint Likert-type scale. A total of 254 responses were gathered, 253 of which were complete and included for the final analysis.

\section{Data analysis}

The statistical software program SPSS 24 (Statistical Package for Social Sciences) was used for the analysis. Statistical procedures used to analyse the collected data included factor analysis and regression analysis (simple regression analysis). A first-order factor analysis was conducted by means of an exploratory factor analysis (EFA), which is necessary to determine whether constructs qualify to be used in their original forms or whether any constructs should be included or excluded (Yong \& Pearce 2013). Confirmatory factor analysis (CFA), which forms part of the second-order analysis, was conducted to test the validity of constructs and hypotheses (Pallant 2013). Simple regression analysis was used to explain the relationship between the independent variables (corporate image, service quality, perceived value, customisation and trust), the intervening variable (customer satisfaction) and the dependent variable (customer loyalty). A preliminary analysis 
was conducted to ensure that there were no violations of the underlying assumptions for performing a simple regression analysis. This type of regression analysis was selected to avoid multicollinearity because of the independent variables being highly correlated (Pallant 2013). In addition, the Pearson's correlation test was used to test for multicollinearity in the relationships between the independent, intervening and the dependent variables. The results indicated that none of the variables correlated higher than 0.9 . Therefore, there was no risk of multicollinearity.

\section{Reliability and validity testing}

The Cronbach's alpha coefficient was calculated for each of the scales that measured the five factors, customer satisfaction and customer loyalty. The reliability statistics are represented in Table 1 and illustrate that the different constructs in the study are all reliable as the values are all above 0.7 . This confirms that the measurement elements used for the study represented internal consistency reliability (De Vos et al. 2011; Malhotra 2012).

\section{Exploratory factor analysis}

The Kaiser-Meyer-Olkin (KMO) measure of sampling adequacy of 0.852 exceeds the cut-off point of 0.7 , with a significance level of $p<0.0005$ for the Bartlett's test of sphericity signifying the factorability of the correlation matrix (Pallant 2013). The communalities for all items are above the cut-off point of 0.3 , ranging between 0.503 and 0.935 . Seven factors with an eigenvalue $\geq 1$ have been extracted, explaining $66.89 \%$ of the variance. This is above the recommended minimum of $60 \%$. The reproduced correlation matrix indicates only $3 \%$ non-redundant residuals. This is below the permissible maximum of $5 \%$ non-redundant residuals. The pattern matrix indicates that all items load above 0.5 on a single factor, with loadings ranging between 0.804 and 0.921, while the average loadings per factor all exceed 0.7 . Convergent validity of the scale measuring the constructs of

TABLE 1: Results of the Cronbach's alpha test.

\begin{tabular}{lc}
\hline Construct & Cronbach's alpha \\
\hline Corporate image & 0.885 \\
Service quality & 0.933 \\
Perceived value & 0.902 \\
Customisation & 0.917 \\
Trust & 0.955 \\
Customer satisfaction & 0.954 \\
Customer loyalty & 0.966 \\
\hline
\end{tabular}

the study can therefore be confirmed. Discriminant validity of these scales can also be confirmed because none of the items cross load at above 0.2 , and the factor correlation matrix shows that pairs of factors share less than $46 \%$ of the variance.

\section{Confirmatory factor analysis}

Confirmatory factor analysis (CFA) is used as a tool to examine the nature and extent of interrelationships between observed and latent constructs (Jackson, Purc-Stephenson \& Gillaspy 2009; Schreiber et al. 2006). This study selected and adapted scale items from the existing scales, and conducting a confirmatory analysis will thus determine whether the items within each construct are applicable (Pallant 2013). Table 2 includes the results from the CFA.

There is a few goodness-of-fit indices that are taken into consideration when conducting a CFA. The first measure to be heeded is the Mardia's coefficient. It is used to determine whether the factors are multivariate normally distributed. If Mardia's coefficient is less than 3, then there is multivariate normality (Ullman 2006). All items for service quality, perceived value and trust have multivariate normal distribution and therefore allow for the use of maximum likelihood estimates. The factors of corporate image, customisation, customer satisfaction and customer loyalty are not normally distributed. Therefore, they cannot make use of maximum likelihood estimates. For the purpose of this study, chi-squared $\left(\chi^{2}\right)$ test, degrees of freedom (df), comparative fit index (CFI), standardised root mean squared residual (SRMR) and the root mean square error of approximation (RMSEA) were reviewed and reported on. To determine $\chi^{2}$, the maximum likelihood and $\mathrm{df}$ are used. According to Schreiber et al. (2006), values for $\chi^{2} / \mathrm{df}$ of between 2 and 5 showing a good fit are used. The value for $\chi^{2} / \mathrm{df}$ for corporate image $(0.790)$ was lower than 2 , indicating that the factor may have an over-fit and this could mean that the items in the questionnaire may be too closely related. All other values for the selected variables are larger than 2 and this indicates good fit. The CFI measure of good fit includes values $\geq 0.90$ (Schreiber et al. 2006). All the values for CFI (except corporate image) for all the factors ranged between 0.942 and 1.000 . These values indicate a good fit. The value for the corporate image of CFI $=1.000$ indicates a possible over-fit. Standardised root mean squared residual values of 0.08 or lower indicate a good fit (Schreiber et al. 2006). The results show that all SRMR values for all the variables were lower than 0.08 and ranged from 0.02 to 0.033 . All factors are

TABLE 2: Confirmatory factor analysis results.

\begin{tabular}{|c|c|c|c|c|c|c|c|c|}
\hline Model & Mardia's coefficient & $\chi^{2}$ & df & $\chi^{2} / \mathbf{d f}$ & CFI & SRMR & RMSEA & RMSEA $90 \% \mathrm{Cl}$ \\
\hline Corporate image & 4.366 & 1.579 & 2 & 0.790 & 1.000 & 0.011 & 0.000 & 0.000: 0.109 \\
\hline Service quality & 1.5998 & 18.496 & 2 & 9.248 & 0.981 & 0.02 & 0.181 & $0.111: 0.260$ \\
\hline Perceived value & 2.0547 & 24.126 & 2 & 12.063 & 0.970 & 0.033 & 0.210 & $0.140: 0.288$ \\
\hline Customisation & 6.2436 & 5.932 & 2 & 2.966 & 0.997 & 0.014 & 0.072 & $0.000: 0.160$ \\
\hline Trust & 1.117 & 33.978 & 2 & 16.989 & 0.972 & 0.018 & 0.252 & $0.181: 0.329$ \\
\hline Customer satisfaction & 10.4051 & 15.364 & 2 & 7.682 & 0.994 & 0.013 & 0.122 & $0.052: 0.204$ \\
\hline Customer loyalty & 15.2806 & 142.897 & 14 & 10.207 & 0.972 & 0.028 & 0.136 & $0.107: 0.165$ \\
\hline
\end{tabular}

$\mathrm{CFI}$, comparative fit index; SRMR, standardised root mean squared residual; RMSEA, root mean square error of approximation; $\mathrm{Cl}$, confidence interval. 
therefore a good fit. When reporting on RMSEA values, all values smaller than 0.08 indicate acceptable fit, any values below 0.05 indicate good fit and values smaller than 0.01 indicate exceptionally good fit (Schreiber et al. 2006). The RMSEA values for corporate image (0.000) indicate an exceptionally good fit, while the other factor values above 0.05 , but below 0.08 , indicate an acceptable fit (service quality) (0.006), perceived value (0.006), customisation (0.007) and trust (0.006). To assess the closeness of fit of the hypotheses, the $90 \%$ confidence interval (CI) is considered. All values with a RMSEA value of less than 0.08 are considered to have a good fit. When all measures of good fit are considered, it can be concluded that the model provides an adequate representation of the covariance between the observed variables.

\section{Ethical consideration}

The author confirms that ethical clearance was not required for the study.

\section{Results}

\section{Profile demographics}

The results indicated that the respondents were predominantly male $(77 \%)$ and white people $(71 \%)$. The second largest ethnic group was black people $(14.2 \%)$, and the smallest ethnic representation was Asian people (1.2\%). Not all respondents indicated their age group $(1.2 \%)$ or their level of education $(0.4 \%)$; however, the majority of the respondents fell within the 31-40 age groups (64\%) and held an undergraduate degree $(54.2 \%)$. In terms of the decisionmaking level, most respondents indicated that they were influencers (36\%), with users $(27.7 \%)$ and decision-makers (27.3\%) also having substantive influence in the decisionmaking process.

\section{Regression analysis and hypothesis testing}

\section{The influence of corporate image, service quality, perceived value, customisation and trust on customer loyalty}

The results of the simple regression analysis displaying the relationships between the independent variables (corporate image, service quality, perceived value, customisation, trust) and the dependent variable (customer loyalty) are shown in Table 3 .

The $R^{2}$ values for corporate image (0.603), service quality (0.599), perceived value (0.642), customisation (0.658) and trust (0.691) indicate the extent to which each independent variable explains the variance of customer loyalty, as follows: corporate image $60.3 \%$, service quality $59.9 \%$, perceived value

TABLE 3a: Influence of the independent variables on the dependent variable. Model 1 summary.

\begin{tabular}{|c|c|c|c|c|}
\hline Factor & $\boldsymbol{R}$ & $R$ square & Adjusted $R$ square & Standard error of the estimate \\
\hline Corporate image & 0.777 & 0.603 & 0.601 & 0.892 \\
\hline Service quality & 0.774 & 0.599 & 0.598 & 0.896 \\
\hline Perceived value & 0.801 & 0.642 & 0.641 & 0.847 \\
\hline Customisation & 0.811 & 0.658 & 0.657 & 0.828 \\
\hline Trust & 0.831 & 0.691 & 0.690 & 0.787 \\
\hline
\end{tabular}

$R$, correlation coefficient.

TABLE 3b: Influence of the independent variables on the dependent variable. ANOVA.

\begin{tabular}{|c|c|c|c|c|c|c|}
\hline Factor & Model 1 & Sum of squares & df & Mean square & $F$ & Sig. \\
\hline \multirow[t]{3}{*}{ Corporate image } & Regression & 303.249 & 1 & 303.249 & 381.216 & 0.000 \\
\hline & Residual & 199.665 & 251 & 0.795 & - & - \\
\hline & Total & 502.914 & 252 & - & - & - \\
\hline \multirow[t]{3}{*}{ Service quality } & Regression & 301.357 & 1 & 301.357 & 357.282 & 0.000 \\
\hline & Residual & 201.557 & 251 & 0.803 & - & - \\
\hline & Total & 502.914 & 252 & - & - & - \\
\hline & Residual & 179.887 & 251 & 0.717 & - & - \\
\hline & Total & 502.914 & 252 & - & - & - \\
\hline \multirow[t]{3}{*}{ Customisation } & Regression & 330.938 & 1 & 330.938 & 483.006 & 0.000 \\
\hline & Residual & 171.976 & 251 & 0.685 & - & - \\
\hline & Total & 502.914 & 252 & - & - & - \\
\hline \multirow[t]{2}{*}{ Trust } & Regression & 347.447 & 1 & 347.447 & 560.949 & 0.000 \\
\hline & Residual & 155.467 & 251 & 0.619 & - & - \\
\hline
\end{tabular}

df, degrees of freedom; $F, F$ statistic; Sig., significance.

TABLE 3c: Influence of the independent variables on the dependent variable. Coefficients.

\begin{tabular}{lcccc}
\hline Model & Corporate image & Service quality & Perceived value & Customisation \\
\hline Constant & -1.136 & 0.0134 & -0.680 & -1.184 \\
Unstandardised coefficients (B) & 1.051 & 0.9640 & 1.038 & 1.124 \\
Standardised coefficients (Beta) & 0.777 & 0.7740 & 0.801 & 0.505 \\
Sig. & 0.000 & 0.0000 & 0.000 & 0.811 \\
\hline
\end{tabular}

Sig., significance. 
$64.2 \%$, customisation $65.8 \%$ and trust $69.1 \%$. The $p$-value (sig.) for all the independent variables is 0.000 . This illustrates that correlation exists between the stated independent variables and the dependent variable (customer loyalty) and indicates that all the independent variables are jointly significant in predicting customer loyalty. The unstandardised beta coefficients for each independent variable were analysed, and the relationship between the independent variables and the dependent variable was found to be significant (a $p$-value of less than 0.05). The standardised coefficients were evaluated, and it was found that trust $(0.831)$ had the most influence on customer loyalty, followed by customisation (0.811), perceived value $(0.801)$, corporate image $(0.777)$ and service quality (0.774). It can be concluded that hypotheses H7, H8, H9, H10 and $\mathrm{H} 11$ are accepted.

\section{The influence of corporate image, service quality, perceived value, customisation and trust on customer satisfaction}

Simple regression analysis was used to explain the relationship between the independent variables (corporate image, service quality, perceived value, customisation and trust) and the intervening variable (customer satisfaction). The results of the simple regression analysis are shown in Table 4.
Table 4 reflects the $R^{2}$ values for corporate image (0.541), service quality $(0.617)$, perceived value $(0.662)$, customisation (0.629) and trust (0.744), which indicate the extent to which each independent variable explains the variance of the dependent variable, as follows: corporate image $54.1 \%$, service quality $61.7 \%$, perceived value $66.2 \%$, customisation $62.9 \%$ and trust $74.4 \%$. The $p$-value (sig.) is 0.000 . The unstandardised beta coefficients for each independent variable were analysed, and the relationship between the independent variables and the dependent variable was found to be significant (a $p$-value of less than 0.05 ). It can be concluded that hypotheses $\mathrm{H} 1, \mathrm{H} 2$, H3, H4 and H5 are accepted. The standardised coefficients were evaluated, and it was found that trust (0.863) had the most influence on customer satisfaction, followed by perceived value $(0.815)$, customisation $(0.794)$, service quality $(0.785)$ and corporate image (0.736).

\section{The influence of customer satisfaction on customer loyalty}

In alignment with the second research objective, simple multiple regression analysis was used to explain the relationship between the intervening variable of customer satisfaction and the dependent variable of customer loyalty. The Pearson's correlation $p$-value is 0.000 , which is acceptable

TABLE 4a: Influence of the independent variables on the intervening variable. Model 1 summary.

\begin{tabular}{|c|c|c|c|c|}
\hline Factor & $\boldsymbol{R}$ & $R$ square & Adjusted $R$ square & Standard error of the estimate \\
\hline Corporate image & 0.736 & 0.541 & 0.540 & 0.788 \\
\hline Service quality & 0.785 & 0.617 & 0.615 & 0.720 \\
\hline Perceived value & 0.815 & 0.664 & 0.662 & 0.675 \\
\hline Customisation & 0.794 & 0.630 & 0.629 & 0.707 \\
\hline Trust & 0.863 & 0.745 & 0.744 & 0.588 \\
\hline
\end{tabular}

$R$, correlation coefficient.

TABLE 4b: Influence of the independent variables on the intervening variable. ANOVA

\begin{tabular}{|c|c|c|c|c|c|c|}
\hline Factor & Model 1 & Sum of squares & df & Mean square & $F$ & Sig. \\
\hline \multirow[t]{3}{*}{ Corporate image } & Regression & 184.029 & 1 & 184.029 & 296.347 & 0.000 \\
\hline & Residual & 155.869 & 251 & 0.621 & - & - \\
\hline & Total & 339.897 & 252 & - & - & - \\
\hline \multirow[t]{3}{*}{ Service quality } & Regression & 209.679 & 1 & 209.679 & 404.162 & 0.000 \\
\hline & Residual & 130.219 & 251 & 0.519 & - & - \\
\hline & Total & 339.897 & 252 & - & - & - \\
\hline \multirow[t]{3}{*}{ Perceived value } & Regression & 225.613 & 1 & 225.613 & 495.510 & 0.000 \\
\hline & Residual & 114.284 & 251 & 0.455 & - & - \\
\hline & Total & 339.897 & 252 & - & - & - \\
\hline \multirow[t]{3}{*}{ Customisation } & Regression & 214.281 & 1 & 214.281 & 428.167 & 0.000 \\
\hline & Residual & 125.616 & 251 & 0.500 & - & - \\
\hline & Total & 339.897 & 252 & - & - & - \\
\hline \multirow[t]{2}{*}{ Trust } & Regression & 253.129 & 1 & 253.129 & 732.239 & 0.000 \\
\hline & Residual & 86.769 & 251 & 0.346 & - & - \\
\hline
\end{tabular}

$\mathrm{df}$, degrees of freedom; $F, F$ statistic; Sig., significance.

TABLE 4c: Influence of the independent variables on the intervening variable. Coefficients.

\begin{tabular}{lcccc}
\hline Model & Corporate image & Service quality & Perceived value & Customisation \\
\hline Constant & 0.211 & 0.932 & 0.347 & 0.062 \\
Unstandardised coefficients (B) & 0.818 & 0.804 & 0.867 & 0.428 \\
Standardised coefficients (Beta) & 0.736 & 0.785 & 0.815 & 0.904 \\
Sig. & 0.000 & 0.000 & 0.000 & 0.794 \\
\hline
\end{tabular}

Sig., significance. 
TABLE 5a: Influence of the intervening variable on the dependent variable. Model 1 summary.

\begin{tabular}{lcccc}
\hline Model & $\boldsymbol{R}$ & $\boldsymbol{R}$ square & $\begin{array}{c}\text { Adjusted } \boldsymbol{R} \\
\text { square }\end{array}$ & $\begin{array}{c}\text { Standard error of } \\
\text { the estimate }\end{array}$ \\
\hline 1 & 0.915 & 0.838 & 0.837 & 0.570 \\
\hline
\end{tabular}

$R$, correlation coefficient.

TABLE 5b: Influence of the intervening variable on the dependent variable. ANOVA.

\begin{tabular}{lccccc}
\hline Model & $\begin{array}{c}\text { Sum of } \\
\text { squares }\end{array}$ & df & $\begin{array}{c}\text { Mean } \\
\text { square }\end{array}$ & $\boldsymbol{F}$ & Sig. \\
\hline Regression & 421.4627 & 1 & 421.463 & 1298.780 & 0.000 \\
Residual & 81.457 & 251 & 0.325 & - & - \\
\hline Total & 502.914 & 252 & - & - & - \\
\hline
\end{tabular}

$\mathrm{df}$, degrees of freedom; $F, F$ statistic; Sig., significance.

TABLE 5c: Influence of the intervening variable on the dependent variable. Coefficients.

\begin{tabular}{lcc}
\hline Model & (Constant)/Loyalty & Customer satisfaction \\
\hline Unstandardised coefficients (B) & -0.799 & 1.114 \\
Standardised coefficients (Beta) & - & 0.915 \\
Sig. & 0.000 & 0.000 \\
\hline
\end{tabular}

Sig., significance.

(according to Pallant 2013) and confirms that the intervening variable (customer satisfaction) and the dependent variable (customer loyalty) are strongly correlated. The results of the simple regression analysis (to evaluate the relationship between customer satisfaction and customer loyalty) are shown in Table 5.

Based on the results in Table 5, the $R^{2}$ value was 0.838 , indicating that $83.8 \%$ of variance in the dependent variable (customer loyalty) is explained by the intervening variable (customer satisfaction). The $p$-value (sig.) is 0.00 . This indicates that correlation between the intervening variable and the dependent variable exists, and therefore customer satisfaction is significant in predicting customer loyalty. The standardised coefficient was also evaluated, and it was found that customer satisfaction is very strong in influencing customer loyalty, with a beta value of 0.915 . It can therefore be concluded that $\mathrm{H} 6$, which postulates a positive relationship between customer satisfaction and intentional customer loyalty, is accepted.

\section{Discussion and implications Theoretical implications}

This study makes several theoretical contributions. Firstly, the results confirm that the scales of measurements used to measure corporate image, service quality, perceived value, customisation, trust, customer satisfaction and customer loyalty are both reliable and valid. The proposed model has been verified, confirming the relationships between the antecedents of customer satisfaction and customer loyalty within an ICT industry in South Africa. Trust was established as the most significant variable in predicting both customer satisfaction and customer loyalty, followed by perceived value and customisation. Trust is therefore the most important factor for securing customer satisfaction and customer loyalty in B2B relationships in the ICT industry of an emerging African market.
Secondly, the customer satisfaction experiences of business customers in relation to mobile ICT business service providers in an emerging market do lead to the customer loyalty of this customer group. Thus, the study supports the claims made in theory that the constructs driving customer satisfaction do indeed influence their loyalty towards ICT business service providers in an emerging market context. Therefore, the findings of this study support the empirical research work of Lewis and Soureli (2006), Moolla and Bischoff (2012), and Tu et al. (2011), who established that corporate image, service quality, perceived value, customisation and trust have a direct and strong influence on the customer satisfaction and ultimate loyalty of business customers. Thirdly, the study contributes to customer satisfaction and customer loyalty theory, as the proposed model explains the influence of corporate image, service quality, perceived value, customisation and trust on customer satisfaction, eventually leading to customer loyalty. Consequently, the positive influence of customer satisfaction on customer loyalty can assist ICT business service providers in South Africa to achieve increased market share, greater profits and a superior competitive advantage.

\section{Managerial implications}

From a managerial perspective, the study provides guidance for the ICT industry in emerging markets in identifying and understanding how corporate image, service quality, perceived value, customisation and trust influence customer satisfaction, eventually fostering customer loyalty. Relationships with customers are critical to secure business survival in highly competitive markets and also to establish a sustainable competitive advantage (Bhat \& Darzi 2016). The following broad guidelines will aid ICT business service providers to improve customer satisfaction and ultimately customer loyalty.

\section{Investing in customer relationship management to enhance customer satisfaction and strengthen customer loyalty}

Guideline 1. The investment in CRM should be driven throughout the organisation and form the core of the corporate culture. Satisfying the customer in a credible manner (delivering on every promise) should be driven by example from executive level. Building and maintaining relationships with customers must become everyone's responsibility.

Guideline 2. Each customer contact department should be enabled to provide the best service to customers. This involves delegating to employees the authority that would enable them to take immediate action to resolve customer requirements. Continuous training on issues relating to face-to-face customer care skills, how to deal with difficult customers and how to engage customers through online platforms should be implemented.

Guideline 3. The importance of relationship marketing and the practical methods used to develop and maintain relationships with customers must be a core component of all training. Employees must be made aware of how their function should contribute towards customer satisfaction. 
Guideline 4. Encouraging the entire organisation to focus on satisfying customers should ensure that every encounter between a customer and the service provider is pleasant. Tailoring CRM for each function and helping employees to understand their role in keeping the customer satisfied will assist in employees taking ownership for managing relationships with customers.

Guideline 5. Customers should be made to feel that they are an important component for the survival of their service provider and that the service provider will always act in their best interest. With each successful encounter, trust will be strengthened. Each effort that is made to satisfy the customer will contribute towards customer loyalty.

Guideline 6. To retain the loyalty of their customers, service providers should maintain a good reputation, adhere to regulations in the industry, propose solutions that customers really need and offer services that are superior to those of competitors. Customers should also be rewarded for their loyalty through complimentary products and services and discounts because the value of B2B deals is often substantial. This will ensure that customers return with future business, increasing profitability and competitiveness.

\section{Understanding customer needs to enhance customer satisfaction and strengthen customer loyalty}

Guideline 1. Understanding customer needs and expectations in depth will require extensive business planning. This should be a formalised component of dealing with customers, allowing all parties involved in service delivery to be aligned internally and with the customer. A formal process to this end should become a critical part of the customer management strategy, and it must be shared with the entire organisation to ensure alignment and consistency in delivering service excellence.

Guideline 2. Service providers should also understand, monitor and manage the factors in the customer's immediate environment that could influence their decisions. This will allow for proactive suggestions to customers and enable them to view their service provider as a trusted advisor.

Guideline 3. Customers should be made aware of the efforts made by the service provider to impact and change society through corporate social responsibility. This provides another opportunity to engage directly with customers in an informal setting, to build relationships, to strengthen organisational image and to foster loyalty to the organisation.

\section{Limitations of the study}

This study is limited by the fact that only five antecedents, namely corporate image, service quality, perceived value, customisation and trust, are considered in a single-service setting. However, the study does provide insight regarding the selected antecedents and their influence on the satisfaction and loyalty of business customers in an ICT service provider context. Understanding these factors will empower the ICT industry to satisfy the needs of their business customers and secure their loyalty in the long term.

\section{Conclusion}

The aim of the study was to investigate the influence of corporate image, service quality, perceived value, customisation and trust on customer loyalty through customer satisfaction as the intervening variable at an ICT business in South Africa. The results established that having a long-term relationship with customers will encourage prolonged investment with the service provider. The ultimate objective of CRM is to influence customer attitudes and behaviour towards a service provider. These attitudes and behaviours influence the customer's intention to engage in repurchase behaviour and to resist the urge to switch to a competitor (Agyei \& Kilika 2014). It is therefore recommended that the investment in CRM should be driven throughout the organisation and should form the core of the corporate culture. Satisfying the customer in a credible manner (delivering on every promise) should be driven by example from executive level. Building and maintaining relationships with customers must become everyone's responsibility. Each customer contact department should be enabled to provide the best service to customers. This involves giving employees a certain delegation of authority, which enables them to take immediate action to resolve customer requirements. Continuous training on issues relating to face-to-face customer care skills, how to deal with difficult customers and providing knowledge on how to engage customers through online platforms should be implemented.

\section{Acknowledgements}

This work is based on the Master's degree dissertation of Mpho Hlefana, entitled 'Factors influencing business-tobusiness loyalty at a mobile service provider', submitted to the University of Johannesburg. The co-authors of this article were the supervisors of the dissertation.

\section{Competing interests}

The authors declare that they have no financial or personal relationships that may have inappropriately influenced them in writing this article.

\section{Authors' contributions}

M.H. was the project leader and was responsible for the problem formulation, literature review, methodology formulation and statistical analyses. M.R.-L. and B.E.S.-M. made conceptual contributions.

\section{Funding information}

This research received no specific grant from any funding agency in the public, commercial or not-for-profit sectors.

\section{Data availability statement}

Data sharing is not applicable to this article as no new data were created or analysed in this study. 


\section{Disclaimer}

The views and opinions expressed in this article are those of the authors and do not necessarily reflect the official policy or position of any affiliated agency of the authors.

\section{References}

Accenture, 2012, Achieving high performance by refocusing on more profitable businessto-business (B2B) models: How ICT companies can drive higher value in their $B 2 B$ business, viewed 17 September 2018, from https://www.scribd.com/ document/216643034/Accenture-High-Performance-Through-More-ProfitableBusiness-to-Business-Models.

Agyei, P.M. \& Kilika, J.M., 2014, 'Relationship between corporate image and customer loyalty in the mobile telecommunication market in Kenya', Management 2(5), 299-308.

Ali, F., Kim, W.G., Li, J. \& Jeon, H.M., 2016, 'Make it delightful: Customers' experience, satisfaction and loyalty in Malaysian theme parks', Journal of Destination Marketing \& Management 7(1), 1-11. https://doi.org/10.1016/j.jdmm.2016.05.003

Ariff, M.S.B.M., Fen, H.S., Zakuan, N., Ishak, N. \& Ismail, K., 2012, 'Relationship between customers' perceived values, satisfaction and loyalty of mobile phone users', Review of Integrative Business and Economics Research 1(1), 126-135.

Bhat, S.A. \& Darzi, M.A., 2016, 'Customer relationship management', International Journal of Bank Marketing 34(3), 388-410. https://doi.org/10.1108/IJBM-112014-0160

Bilgihan, A., 2016, 'Gen Y customer loyalty in online shopping: An integrated mode of trust, user experience and branding', Computers in Human Behavior 61(C), 103-113. https://doi.org/10.1016/j.chb.2016.03.014

Bojei, J., Julian, C.C., Wel, C.A.B.C. \& Ahmed, Z.U., 2013, 'The empirical link between relationship marketing tools and consumer retention in retail marketing', Journal of Consumer Behaviour 12(3), 171-181. https://doi.org/10.1002/cb.1408

Botha, G.J. \& Van Rensburg, A.C., 2010, 'Proposed business process improvement model with integrated customer experience management: General articles', South African Journal of Industrial Engineering 21(1), 45-57. https://doi.org/ 10.7166/21-1-65

Carvajal, M., Ruzzi, A.L., Nogales, A.D. \& Moreno, V.M., 2011, 'The impact of personalization and complaint handling on customer loyalty', African Journal of Business Management 5(34), 13187-13196. https://doi.org/10.5897/AJBM11.1162

Cheng, J.C., Chen, C.Y., Yen, C.H. \& Teng, H.Y., 2017, 'Building customer satisfaction with tour leaders: The roles of customer trust, justice perception, and cooperation in group package tours', Asia Pacific Journal of Tourism Research 22(4), 395-407.

Chuah, H.W., Marimuthu, M. \& Ramayah, T., 2014, 'The effect of perceived value on the loyalty of Generation $Y$ mobile internet subscribers: A proposed conceptual framework', Procedia - Social and Behavioral Sciences 130, 532-541. https://doi. org/10.1016/j.sbspro.2014.04.062

Coelho, P.S. \& Henseler, J., 2012, 'Creating customer loyalty through service customization', European Journal of Marketing 46(3/4), 331-356. https://doi. org/10.1108/03090561211202503

Dagger, T.S. \& Sweeney, J.C., 2007, 'Service quality attribute weights: How do novice and longer-term customers construct service?', Journal of Service Research 10(1), 22-42. https://doi.org/10.1177/1094670507303010

Davies, G. \& Chun, R., 2002, 'Gaps between the internal and external perceptions of the corporate brand', Corporate Reputation Review 5(2/3), 144-158. https://doi. org/10.1057/palgrave.crr.1540171

Department of Telecommunications and Postal Services, 2014, Policy options: ICT industry growth, viewed 2 October 2018, from www.gov.za/sites/www.gov.za/ industry growth, viewed 2 October 2018
files/DTPS-annual-report-2014-15.pdf.

De Vos, A.S., Delport, C.S.L., Fouché, C.B. \& Strydom, H., 2011, Research at grass roots: A primer for the social science and human professions, 4th edn., Van Schaik, roots: $A$ prim
Pretoria.

Du Plessis, L., 2010, 'Customer relationship management and its influence on customer loyalty at Liberty Life in South Africa', Doctoral dissertation, University of Johannesburg.

Gong, T. \& Yi, Y., 2018, 'The effect of service quality on customer satisfaction, loyalty, and happiness in five Asian countries', Psychology Marketing 35(6), 427-442. https://doi.org/10.1002/mar.21096

Haghighikhah, M., Khadang, M. \& Arabi, M., 2016, 'Internal marketing: Employee satisfaction and word of mouth in Guilan's Saderat Bank', International Journal of Marketing Studies 8(2), 147-158. https://doi.org/10.5539/ijms.v8n2p147

Handriana, T., 2016, 'The role of relationship marketing in small and medium enterprises (SMEs)', Jurnal Pengurusan 48(2016), 137-148. https://doi. org/10.17576/pengurusan-2016-48-11

Jackson, D.L., Gillaspy Jr, J.A. \& Purc-Stephenson, R., 2009, 'Reporting practices in confirmatory factor analysis: An overview and some recommendations', Psychological methods 14(1), 6 .

Jemaa, A.M.B. \& Tournois, N., 2014, 'Relationship marketing key concepts as relationship value determinant', Journal of Marketing Research and Case Studies 2014, 1-17. https://doi.org/10.5171/2014.201710

Jokela, P. \& Söderman, A., 2017, 'Re-examining the link between fairness and commitment in buyer-supplier relationships', Journal of Purchasing and Supply Management 23(4), 268-279. https://doi.org/10.1016/j.pursup.2017.08.003
Larentis, F., Antonello, C.S. \& Slongo, L.A., 2017, 'Organizational culture and relationship marketing: An interorganizational perspective', Review of Business Management 20(1), 37-56. http://doi.org/10.7819/rbgn.v20i1.3688

Lassoued, R. \& Hobbs, J.E., 2015, 'Consumer confidence in credence attributes: The role of brand trust', Food Policy 52(2015), 99-107. https://doi.org/10.1016/j. foodpol.2014.12.003

Lee, H.S., 2010, 'Factors influencing customer loyalty of mobile phone service: Empirical evidence from Koreans', Journal of Internet Banking and Commerce 15(2), 1-14.

Lewis, B. \& Soureli, M., 2006, 'The antecedents of consumer loyalty in retail banking', Journal of Consumer Behaviour 5(1), 15-31. https://doi.org/10.1002/cb.46

Malhotra, N.K., 2012, Basic marketing research: Integration of social media, Pearson, Boston, MA.

Malik, M.E., Ghafoor, M.M. \& Iqbal, H.K., 2012, 'Impact of brand image, service quality and price on customer satisfaction in Pakistan telecommunication sector', International Journal of Business and Social Science 3(23), 123-129.

Melewar, T.C., Foroudi, P., Gupta, S., Kitchen, P.J. \& Foroudi, M.M., 2017, 'Integrating identity, strategy and communications for trust, loyalty and commitment', European Journal of Marketing 51(3), 572-604. https://doi.org/10.1108/EJM08-2015-0616

Moolla, A.I. \& Bischoff, C.A., 2012, ‘A model to measure the brand loyalty for fast moving consumer goods', Journal of Social Sciences 31(1), 73-87. https://doi.org/ 10.1080/09718923.2012.11893016

National Treasury, 2016, Budget review, viewed 1 October 2018, from www.treasury. gov.za/documents/national\%20budget/2016/review/FullReview.pdf.

Ndubisi, N.O., Malhotra, N.K \& Chan, K.W., 2009, 'Relationship marketing, customer satisfaction and loyalty: A theoretical and empirical analysis from an Asian perspective, Journal of International Consumer Marketing 21(1), 5-16.

Ndubisi, N.O., Malhotra, N.K. \& Miller, G.L., 2015, 'Customer reactions to conflict management: A review and empirical evidence from two service industries', in N.K. Malhotra (ed.), Review of marketing research, special issue, vol. 10, pp. 63-96, Emerald, Bingley, West Yorkshire.

Negi, R. \& Ketema, E., 2010, 'Relationship marketing and customer loyalty: The Ethiopian mobile communications perspective', International Journal of Marketing Management 5(10), 113-124.

Nguyen, N., Leclerc, A. \& LeBlanc, G., 2013, 'The mediating role of customer trust on customer loyalty', Journal of Service Science and Management 6(1), 96-109. https://doi.org/10.4236/jssm.2013.61010

Nuseir, M.T. \& Madanat, H., 2015, '4Ps: A strategy to secure customers' loyalty via customer satisfaction', International Journal of Marketing Studies 7(4), 78-86. https://doi.org/10.5539/ijms.v7n4p78

Nyadzayo, N.W. \& Roberts-Lombard, M., 2010, 'A theoretical analysis of the mediating role of customer relationship management performance on customer retention in South African motor dealerships', Journal of Contemporary Management 7(1), 167-190.

Pallant, J. 2013, SPSS Survival manual: A step by step guide to data analysis using IBM SPSS, 6th edn., McGraw-Hill, Maidenhead.

Petzer, D.J. \& De Meyer, C.F., 2011, 'The perceived service quality, satisfaction and behavioural intent towards cellphone network service providers: A generational perspective', African Journal of Business Management 5(17), 7461-7473. https://doi.org/10.5897/AJBM11.302

Quoquab, F., Basiruddin, R. \& Rasid, S.Z.A., 2013, 'A structural look at service loyalty: Role of service quality, corporate image, and trust', American Journal of Economics 3(5C), 177-183. https://doi.org/10.5923/c.economics.201301.30

Rootman, C., Tait, M. \& Sharp, G., 2011, 'Relationship marketing and customer retention lessons for South African banks', Southern African Business Review 15(3), 184-206.

Schreiber, J.B., Nora, A., Stage, F.K., Barlow, E.A. \& King, J., 2006, 'Reporting structura equation modeling and confirmatory factor analysis results: A review', The Journal of educational research 99(6), 323-338.

Selvam, M. \& Kalyanasundaram, P., 2015, 'Global IT/IT enabled services and ICT industry: Growth \& determinants', paper presented at the International Symposium on Emerging Trends in Social Science Research, 3-5 April, Chennai, Symposium on Emerging Trends in Social Science Research, 3-5 April, Chennai,
India, viewed 20 September 2018, from http://globalbizresearch.org/Chennai India, viewed 20 September 2018, fr
Symposium/conference/pdf/C549.pdf.

Statistics South Africa, 2015, Information and communication technology satellite account for South Africa 2012, viewed 2 October 2018, from www.statssa.gov.za/ publications/Report-04-07.../Report-04-07-01January2015.pdf.

Swiss Business Hub South Africa, 2014, Information \& communication technology (ICT) industry - South Africa, viewed 2 October 2018, from https://www.s-ge. com/sites/default/files/private_files/1411_sA_ICT.pdf.

Theron, E., Terblanche, N. \& Boshoff, C., 2008, 'The antecedents of relationship commitment in the management of relationships in business-to-business (B2B) financial services', Journal of Marketing Management 24(9/10), 997-1010. https://doi.org/10.1362/026725708X382019

Theron, E., Terblanche, N.S. \& Boshoff, C., 2012, 'A managerial framework for relationship management in the business-to-business financial services industry', Management Dynamics: Journal of the Southern African Institute for Management Scientists 21(4), 31-52. https://doi.org/10.2501/S1470785310201326

Tu, Y., Li, M. \& Chih, H., 2011, 'The effect of service quality, customer perceived value and satisfaction on loyalty', Journal of Economics \& Behavioral Studies 3(3), 198-212. https://doi.org/10.15294/jdm.v6i1.4296 
Tu, Y., Li, M. \& Hsu, T., 2013, 'The impact of brand image and customer commitment on loyalty: An empirical study of automobile sector', Information Management and loyalty: An empirical study of automobile sector', Information Management and
Business Review 5(4), 181-193. https://doi.org/10.22610/imbr.v5i4.1042.g1042

Ullman, J.B., 2006, 'Structural equation modeling: Reviewing the basics and moving forward', Journal of Personality Assessment 87(1), 35-50. https://doi.org/10.1207/ s15327752jpa8701 03

Upamannyu, N.K., Gulati, C., Chack, A. \& Kaur, G., 2015, 'The effect of customer trust on customer loyalty and repurchase intention: The moderating influence of perceived CSR', International Journal of Research in IT, Management and Engineering 5(4), 1-31.
Van Vuuren, T., Roberts-Lombard, M. \& Van Tonder, E., 2012, 'The relationship between selected variables and customer loyalty within an optometric practice environment', Acta Commercii 1(1), 1-14. https://doi.org/10.4102/ac. practice envir 12137
v12.

Yang, Z. \& Peterson, R.T., 2004, 'Customer perceived value, satisfaction, and loyalty: The role of switching costs', Psychology and Marketing 21(10), 799-822. https:// doi.org/10.1002/mar.20030

Yong, A.G. \& Pearce, S., 2013, 'A beginner's guide to factor analysis: Focusing on exploratory factor analysis', Tutorials in Quantitative Methods for Psychology 9(2), 79-94. https://doi.org/10.20982/tqmp.09.2.p079 